\title{
Pertumbuhan dan produksi tanaman kailan (Brassica oleracea) akibat pemberian mulsa jerami padi dengan takaran yang berbeda
}

\author{
(Growth and production of kailan (Brassica oleracea) due to application of mulch of rice \\ straw with different doses)
}

\author{
A. A. Setiyaningrum, A. Darmawati, dan S. Budiyanto \\ Agroecotechnology, Faculty of Animal and Agricultural Sciences, Diponegoro University \\ Tembalang Campus, Semarang 50275 - Indonesia \\ CorrespondingE-mail: alvianisa02@gmail.com
}

\begin{abstract}
The objective of this research was to examine the effect and quantity of rice straw mulch on the growth and production of kailan. This research was conducted in Aspakusa Makmur Farms Association, Teras, Boyolali and Laboratory of Ecology and Plant Production, Faculty of Animal and Agricultural Sciences, Diponegoro University, Semarang from January $24^{\text {th }}$ to March $24^{\text {th }} 2018$. The research was assigned in completely randomized monofactor design with the factor was M0: control, M1: 2 ton/ha, M2: 4 ton/ha, M3: 6 ton/ha and M4: 8 ton/ha. Parameters observed were plant height, number of leaves, soil and temperature, plant and root wet weight, plant and root dry weight and total chlorophyll content. The results showed that mulch treatment with a dose of 6 tons/ha was able to increase the yield of leaves, root dry weight and total chlorophyll content but did not increase crop yields, soil and temperature, plant and root wet weight, plant dry weight
\end{abstract}

Keyword: Kailan, Mulch, Rice straw

\begin{abstract}
ABSTRAK
Penelitian bertujuan untuk mengkaji pengaruh dan takaran mulsa jerami padi terhadap pertumbuhan dan produksi tanaman kailan. Penelitian dilakukan pada tanggal 24 Januari 2018 - 24 Maret 2018 di Lahan pertanian Asosiasi Aspakusa Makmur Kecamatan Teras Kabupaten Boyolali dan Laboratorium Ekologi dan Produksi Tanaman, Fakultas Peternakan dan Pertanian, Universitas Diponegoro, Semarang. Penelitian disusun dengan rancangan acak lengkap monofaktor dengan perlakuan $\mathrm{M}_{0}$ : kontrol, $\mathrm{M}_{1}$ : jerami padi 2 ton/ha, $\mathrm{M}_{2}$ : jerami padi 4 ton/ha, $\mathrm{M}_{3}$ : jerami padi 6 ton/ha dan $\mathrm{M}_{4}$ : jerami padi 8 ton/ha. Parameter yang diamati adalah tinggi tanaman, jumlah daun, kelembaban dan suhu tanah, berat basah tanaman dan akar, berat kering tanaman dan akar dan kandungan klorofil total. Hasil penelitian menunjukkan bahwa Perlakuan mulsa dengan takaran 6 ton/ha mampu meningkatkan hasil jumlah daun, berat kering akar dan kandungan klorofil total tetapi tidak meningkatkan hasil tinggi tanaman, kelembaban dan suhu tanah, berat basah tanaman dan akar, berat kering tanaman
\end{abstract}

Kata kunci: kailan, mulsa, jerami padi

\section{PENDAHULUAN}

Kailan (Brassica oleraceae) sebagai salah satu jenis sayuran hijau yang mampu mencegah penyakit jantung, stroke, alzheimer dan memiliki kandungan karatenoid sebagai anti kanker. Permintaan kailan selalu meningkat dari tahun ke tahun karena memiliki kandungan gizi yang sangat tinggi namun pasar tidak mampu mencukupi permintaan konsumen karena produksi kalian menurun. Produksi kailan tahun 2012 sebesar $5.320 \mathrm{~kg} / \mathrm{ha}$ dan pada tahun 2014 produksi kailan mengalami penurunan yaitu $3.484 \mathrm{~kg} / \mathrm{ha}$ (Badan Pusat Statistik, 2014). Beberapa faktor yang diduga menjadi penyebab rendahnya hasil tersebut antara lain adalah tidak stabilnya iklim 
mikro, kandungan bahan organik rendah, tingkat kesuburan tanah rendah dan penggunaan benih bermutu rendah. Suhu tanah yang tinggi akan menyebabkan proses penguapan yang tinggi sehingga kandungan air dalam tanah tidak tercukupi. Kelembaban tanah yang rendah akan berpengaruh terhadap menurunnya jasad yang berada di dalam tanah itu sendiri.

Penggunaan mulsa merupakan salah satu alternatif dalam menstabilkan suhu dan kelembabkan serta membantu dalam penyerapan air oleh tanah sehingga akan meningkatkan pertumbuhan dan produksi kailan. Mulsa merupakan material penutup tanaman budidaya yang dimaksudkan untuk menjaga kelembaban tanah serta menekan pertumbuhan gulma dan penyakit sehingga membuat tanaman tumbuh dengan baik. Mulsa terdiri dari dua macam yaitu mulsa organik dan mulsa anorganik. Mulsa anorganik terbuat dari bahan yang sukar terurai sedangkan mulsa organik berasal dari bahanbahan alami yang mudah terurai seperti sisa-sisa tanaman seperti jerami padi. Usaha untuk menstabilkan suhu dan kelembaban tanah dan mudah diperoleh, mulsa yang baik digunakan adalah mulsa jerami padi, yang diberikan dengan cara menutup tanah pada bedengan (Yulinda et al., 2013). Penggunaan mulsa organik jerami padi mampu membantu mempertahankan tanah supaya tidak tercuci oleh air yang terlalu banyak serta mempertahankan agregasi tanah. Keuntungan penggunaan mulsa jerami padi adalah lebih ekonomis, mudah didapatkan, dapat terurai sehingga menambah kandungan bahan organik dalam tanah dan membantu dalam penyerapan air oleh tanah. Penggunaan mulsa organik dari bahan jerami sangat baik untuk di terapkan karena jerami adalah jenis bahan organik yang tidak terdapat kandungan kimia dan dampak dari tanah yang di pakai dalam penanaman menggunakan mulsa organik dari jerami akan lebih subur di banding dengan menggunakan plastik yang akan merusak tanah. Beberapa unsur yang terkandung dalam jerami di antarannya adalah jerami mengandung unsur hara Si 4 - 7\%, K20 1,2 - 1,7\%, P205 0,07 - 0,12\% dan N 0,5 - 0,8\%. Tingkat ketebalan mulsa mempengaruhi pertumbuhan dan produksi tanaman. Ketebalan mulsa yang tinggi menyebabkan cahaya matahari yang diterima permukaan tanah rendah. Akibatnya evaporasi berjalan lambat dan kelembaban tanah akan dapat dipertahankan. Ketika tanah pada kondisi terbuka atau dengan tingkat ketebalan mulsa rendah, kelembaban tanah yang dihasilkan menjadi rendah halini disebabkan oleh tingginya cahaya matahari yang diterima oleh suatu permukaan tanah (Suminarti, 2012).

Hasil produksi tanaman sawi pada saat panen menggunakan aplikasi mulsa jerami, mulsa daun tebu, dan mulsa batang jagung lebih tinggi daripada aplikasi mulsa plastik hitam perak (Sutarto et al., 2016). Residu penggunaan mulsa jerami memberikan respon lebih baik terhadap pertumbuhan dan hasil tanaman sawi dibandingkan tanpa mulsa jerami (Yalang et al., 2016). Pemberian mulsa terhadap pertumbuhan tinggi tanaman sawi diduga memberikan pengaruh yang baik karena adanya mulsa dapat mengeliminir fluktuasi suhu tanah dan meningkatkan daya simpan air tanah sehingga mendukung pertumbuhan awal tanaman (Samiati et al., 2012). Perlakuan mulsa jerami dan mulsa orok-orok lebih baik dibandingkan dengan mulsa kayu apu, mulsa eceng gondok, mulsa kara benguk dan perlakuan tanpa mulsa karena dapat meningkatkan pertumbuhan dan hasil panen buah pada tanaman cabai besar (Damaiyanti et al., 2013). Berdasarkan uraian di atas, tidak diketahui takaran mulsa jerami padi yang efektif untuk mendapatkan hasil produksi tanaman yang berkualitas, maka perlu dilakukan penelitian pemberian mulsa jerami padi dengan takaran yang berbeda-beda pada tanaman kailan.

Penelitian ini bertujuan untuk mengkaji pengaruh mulsa jerami padi terhadap pertumbuhan dan produksi tanaman kailan serta mengkaji takaran mulsa jerami padi yang paling efektif untuk pertumbuhan dan produksi tanaman kailan.

\section{MATERI DAN METODE}

Penelitian ini dilaksanakan selama dua bulan yaitu pada 24 Januari 2018 - 24 Maret 2018 di Lahan pertanian Asosiasi Aspakusa Makmur Kecamatan Teras Kabupaten Boyolali dan Laboratorium Ekologi dan Produksi Tanaman, Fakultas Peternakan dan Pertanian, Universitas Diponegoro, Semarang. 


\section{Materi}

Alat yang digunakan dalam penelitian ini adalah traktor untuk mengolah tanah, cangkul digunakan untuk membuat bedengan, penggaris untuk mengukur tinggi tanaman, tray untuk tempat penyemaian, timbangan untuk menimbang berat kailan, thermo hygrometer untuk mengukur suhu dan kelembaban tanah, kertas label untuk memberi nama dan alat tulis untuk menulis. Bahan yang digunakan untuk penelitian adalah tanah, jerami padi, benih kailan, air, pupuk urea dan kandang sapi.

\section{Metode}

Penelitian dilaksanakan dalam beberapa tahap yaitu persiapan, pelaksanaan, pemeliharaan dan pengolahan data. Tahap persiapan dilaksanakan dengan melakukan analisis mulsa jerami padi dan tanah, menyiapkan benih yang akan disemai pada tray selama 3 minggu, membuat bedengan berukuran $2,1 \mathrm{~m} \times 2,1 \mathrm{~m}$ dengan jarak tanam $30 \mathrm{~cm}$ x $30 \mathrm{~cm}$, kemudian melakukan pemupukan dasar 2 minggu sebelum tanam yaitu dengan pupuk kandang sapi 4,41 $\mathrm{kg} /$ bedeng atau 10 ton/ha, melakukan pemberian mulsa dengan cara menutup tanah menggunakan jerami padi sesuai perlakuan dosis yang berbeda tiap bedeng. Tahap pelaksanaan yaitu dilaksanakan dengan penanaman bibit kailan dengan kedalaman $2 \mathrm{~cm}$ dan jarak antar tanaman dengan mulsa yaitu $10 \mathrm{~cm}$ untuk menghindari adanya patogen yang masih hidup di dalam jerami. Tahap pemeliharaan dilaksanakan dengan melakukan irigasi dua kali dalam seminggu pada pagi hari, melakukan pemupukan lanjutan dilakukan sekali pada saat dua minggu setelah tanam dengan pupuk urea sebanyak 57 gram/bedeng atau 0,13 ton/ha. Mengamati dan menghitung setiap hari sesuai parameter.

\section{Rancangan Percobaan dan Analisis Data}

Penelitian dilakukan menggunakan percobaan monofaktor dengan Rancangan Acak Lengkap (RAL) 5 perlakuan 5 kali ulangan. Perlakuan yang diberikan yaitu takaran mulsa jerami padi $\mathrm{M}_{0}$ : kontrol, $\mathrm{M}_{1}$ : jerami padi 2 ton/ha, $\mathrm{M}_{2}$ : jerami padi 4 ton/ha, $\mathrm{M}_{3}$ : jerami padi 6 ton/ha dan $\mathrm{M}_{4}$ : jerami padi 8 ton $/$ ha. Kombinasi perlakuan sebanyak 5 dengan 5 kali ulangan, sehingga terdapat 25 unit percobaan dimana setiap unit percobaan terdiri dari 49 tanaman kailan.

Data yang diperoleh kemudian diolah dengan analisis ragam (uji $\mathrm{F}$ ) untuk mengetahui pengaruh perlakuan dan apabila ada pengaruh nyata perlakuan dilanjutkan dengan uji DMRT (Duncan Multiple Range Test).

\section{HASIL DAN PEMBAHASAN}

\section{Kelembaban dan Suhu Tanah}

Hasil analisis ragam menunjukkan bahwa mulsa jerami padi memberikan pengaruh yang nyata terhadap kelembaban. Kelembaban tanah pada pemberian mulsa jerami padi yang berbeda setelah 6 minggu tersaji pada Tabel 1 .

Hasil Uji DMRT menunjukkan bahwa perlakuan mulsa jerami padi dengan takaran yang berbeda memberikan hasil perbedaan yang nyata terhadap kelembaban tanah. Takaran mulsa yang tinggi menyebabkan cahaya matahari terhalang masuk pada permukaan tanah dan energi yang diteruskan kedalam tanah menjadi rendah,

Tabel 1. Kelembaban Tanah pada Berbagai Perlakuan.

\begin{tabular}{cc}
\hline Mulsa Jerami Padi (ton/ha) & Kelembaban (\%) \\
\hline 0 & $54,60^{\mathrm{a}}$ \\
2 & $65,60^{\mathrm{b}}$ \\
4 & $76,40^{\mathrm{c}}$ \\
6 & $80,60^{\mathrm{d}}$ \\
8 & $87,40^{\mathrm{e}}$ \\
\hline Rata-rata & 72,92 \\
\hline
\end{tabular}

Superskrip yang berbeda pada kolom yang sama menunjukkan perbedaan nyata $(\mathrm{P}<0,05)$. 
sehingga kelembaban tanah menjadi tinggi. Takaran mulsa yang rendah menyebabkan cahaya matahari mudah untuk masuk pada permukaan tanah dan energi yang diteruskan kedalam tanah menjadi tinggi, sehingga kelembaban tanah menjadi rendah. Berdasarkan tabel diatas menunjukkan bahwa perlakuan mulsa jerami padi dengan takaran yang berbeda terjadi peningkatan yang signifikan terhadap parameter kelembaban tanah. Perlakuan dengan takaran 2 ton/ha sampai 8 ton/ha memberikan hasil kelembaban yang sesuai dengan syarat tumbuh tanaman kailan dibandingkan dengan perlakuan 0 ton/ha. Hal ini dikarenakan kelembaban tanah optimum yang dikehendaki tanaman kailan adalah 60\% - 90\% untuk mendapatkan pertumbuhan yang baik sehingga kelembaban yang sesuai terjadi pada perlakuan 2 ton/ha sampai 8 ton/ha. Perlakuan dengan takaran 8 ton/ha merupakan perlakuan takaran mulsa paling tinggi dibandingakan perlakuan lainnya sehingga semakin tinggi takaran mulsa maka kelembaban tanah semakin tinggi. Menurut Ariffin (2005) semakin besar takaran mulsa jerami padi semakin tinggi angka kelembaban.

Hasil analisis ragam menunjukkan bahwa mulsa jerami padi memberikan pengaruh yang nyata terhadap suhu tanah. Suhu tanah pada pemberian mulsa jerami padi yang berbeda setelah 6 minggu tersaji pada Tabel 2.

Tabel 2. Suhu Tanah pada Berbagai Perlakuan. mulsa jerami padi lainnya. Hal ini dikarenakan suhu optimum yang dikehendaki tanaman kailan adalah $25^{\circ} \mathrm{C}-30^{\circ} \mathrm{C}$ untuk mendapatkan pertumbuhan dan produksi tanaman yang baik. Menurut Suharyanto dan Sulistiawati (2012) kondisi iklim yang dikehendaki untuk pertumbuhan tanaman Kailan adalah daerah yang mempunyai suhu $25^{\circ}-30^{\circ} \mathrm{C}$ serta penyinaran matahari antara 10 - 13 jam/hari. Semakin banyak mulsa yang diaplikasikan pada permukaan tanah maka uap air yang terkandung di dalam tanah semakin tinggi dan tanah akan sulit untuk melakukan evaporasi sehingga suhu tanah menjadi rendah. Semakin sedikit mulsa yang diaplikasikan maka uap air yang terkandung di dalam tanah semakin rendah dan tanah akan mudah untuk melakukan evaporasi sehingga suhu tanah menjadi tinggi maka suhu yang dihasilkan semakin tinggi. Menurut Widyasari et al. (2011) usaha untuk mempertahankan dan mengurangi terjadinya kehilangan air tanah akibat penguapan dapat dilakukan dengan penggunaan mulsa jerami padi, yang juga berfungsi menekan fluktuasi suhu tanah. Pemulsaan yang sesuai dapat mengubah iklim mikro tanah, salah satunya adalah suhu tanah yang mempengaruhi pertumbuhan tanaman.

Tinggi Tanaman Kailan (Brassica oleracea $\mathbf{L}$.)

Hasil analisis ragam menunjukkan bahwa perlakuan mulsa jerami padi tidak memberikan

\begin{tabular}{cc}
\hline Mulsa Jerami Padi (ton/ha) & Suhu $\left({ }^{\circ} \mathrm{C}\right)$ \\
\hline 0 & $29,60^{\mathrm{a}}$ \\
2 & $27,20^{\mathrm{b}}$ \\
4 & $26,80^{\mathrm{b}}$ \\
6 & $25,80^{\mathrm{b}}$ \\
8 & $24,60^{\mathrm{c}}$ \\
\hline Rata-rata & 26,80 \\
\hline
\end{tabular}

Superskrip yang berbeda pada kolom yang sama menunjukkan perbedaan nyata $(\mathrm{P}<0,05)$.

Hasil Uji DMRT menunjukkan bahwa perlakuan mulsa jerami padi terjadi penurunan suhu tanah yang signifikan. Perlakuan mulsa jerami padi 8 ton/ha menunjukkan hasil suhu terendah yaitu $24,60^{\circ} \mathrm{C}$ dibandingkan perlakuan pengaruh nyata terhadap tinggi tanaman setelah 6 minggu. Tinggi tanaman kailan pada pemberian mulsa jerami padi dengan takaran yang berbeda setelah 6 minggu tersaji pada Tabel 3.

Hasil Uji DMRT menunjukkan bahwa 
Tabel 3. Tinggi Tanaman Kailan pada Berbagai Perlakuan.

\begin{tabular}{cc}
\hline Mulsa jerami padi (ton/ha) & Tinggi Tanaman $(\mathrm{cm})$ \\
\hline 0 & 22,02 \\
2 & 23,21 \\
4 & 23,87 \\
6 & 23,66 \\
8 & 21,80 \\
\hline Rata-rata & 22,91 \\
\hline
\end{tabular}

perlakuan mulsa jerami padi tidak berpengaruh nyata pada tinggi tanaman kailan. Hal tersebut dikarenakan perubahan suhu tanah setiap minggu pada setiap perlakuan tidak stabil sehingga menyebabkan pertumbuhan tinggi tanaman terhambat. Menurut Mayun (2007) semakin rendah rata-rata suhu tanah maka akan cenderung semakin rendah rata-rata tinggi tanaman dan semakin tinggi rata-rata jumlah dan berat buah. Hal ini didukung oleh Irfany (2016) yang menyatakan bahwa semakin besar takaran mulsa, maka energi matahari semakin terhalangi masuk kedalam tanah yang mengakibatkan energi yang diperlakukan untuk proses evaporasi tidak tercukupi.

\section{Jumlah Daun Tanaman Kailan}

Hasil analisis ragam menunjukkan bahwa perlakuan mulsa jerami padi memberikan pengaruh nyata terhadap jumlah daun tanaman setelah 6 minggu. Jumlah daun tanaman kailan pada pemberian mulsa jerami padi dengan takaran yang berbeda setelah 6 minggu tersaji pada Tabel 4.
Hasil Uji DMRT menunjukkan bahwa pada perlakuan mulsa jerami memberikan perbedaan nyata terhadap jumlah daun kailan. Hal ini karena dipengaruhi oleh perubahan suhu tanah yang tidak stabil. Hal ini sesuai dengan Trisnaningsih et al. (2015) yang menyatakan bahwa perubahan temperatur dari dingin atau panas yang tidak stabil mempengaruhi kemampuan fotosintesis, translokasi, respirasi dan transpirasi, jika temperatur terlalu dingin atau terlalu tinggi pertumbuhan akan menjadi lambat atau terhenti sama sekali.

\section{Berat Basah Tanaman dan Akar}

Hasil analisis ragam menunjukkan bahwa mulsa jerami padi memberikan pengaruh yang nyata terhadap berat basah tanaman. Berat basah tanaman pada pemberian mulsa jerami padi yang berbeda setelah 6 minggu tersaji pada Tabel 5 .

Hasil Uji DMRT menunjukkan bahwa perlakuan mulsa jerami memberikan perbedaan yang nyata terhadap berat basah tanaman. Berat basah tanaman mengalami peningkatan pada perlakuan 0 ton/ha sampai 4 ton/ha, namun

Tabel 4. Jumlah Daun Tanaman Kailan pada Berbagai Perlakuan.

\begin{tabular}{cc}
\hline Mulsa jerami padi (ton/ha) & Jumlah Daun Tanaman Kailan (helai) \\
\hline 0 & $6,93^{\mathrm{b}}$ \\
2 & $7,66^{\mathrm{ab}}$ \\
4 & $7,83^{\mathrm{ab}}$ \\
6 & $8,64^{\mathrm{a}}$ \\
8 & $6,81^{\mathrm{b}}$ \\
\hline Rata-rata & 7,57 \\
\hline
\end{tabular}

Superskrip yang berbeda pada kolom yang sama menunjukkan perbedaan nyata $(\mathrm{P}<0,05)$. 
Tabel 5. Berat Basah Tanaman pada Berbagai Perlakuan.

\begin{tabular}{cc}
\hline Mulsa Jerami Padi (ton/ha) & Berat Basah Tanaman $(\mathrm{kg})$ \\
\hline 0 & $2,16^{\mathrm{b}}$ \\
2 & $2,35^{\mathrm{b}}$ \\
4 & $3,70^{\mathrm{a}}$ \\
6 & $3,46^{\mathrm{a}}$ \\
8 & $2,03^{\mathrm{b}}$ \\
\hline Rata-rata & 2,74 \\
\hline
\end{tabular}

Superskrip yang berbeda pada kolom yang sama menunjukkan perbedaan nyata $(\mathrm{P}<0,05)$.

kemudian berat basah tanaman menurun pada perlakuan 6 ton/ha dan menurun secara signifikan pada perlakuan 8 ton/ha. Perlakuan mulsa 4 ton/ha memberikan hasil berat basah tanaman lebih tinggi yaitu $3,70 \mathrm{~kg}$ dibandingkan perlakuan lainnya. Hal ini dikarenakan suhu dan kelembaban tanah pada perlakuan 4 ton/ha merupakan suhu dan kelembaban tanah yang dikehendaki oleh tanaman kailan yaitu $76,40 \%$ dan $24^{\circ} \mathrm{C}$ sehingga memberikan hasil berat basah yang tinggi. Hal sesuai dengan pendapat Kartasapoetra (2004) yang menyatakan bahwa manfaat mulsa di antaranya mempertahankan kelembaban tanah dan suhu tanah sehingga mendorong pengambilan unsur hara oleh akar tanaman dan mencegah sinar matahari langsung. Perlakuan 6 ton/ha dan 8 ton/ha suhu tanah menurun dan tidak sesuai dengan suhu yang dikehendaki tanaman kailan sehingga berat basah yang dihasilkan menjadi rendah. Menurut Idris et al. (2017) suhu yang tinggi menyebabkan pertumbuhan kailan tidak subur, kurus, dan produksinya rendah, serta kualitas daun juga rendah.
Hasil analisis ragam menunjukkan bahwa mulsa jerami padi memberikan pengaruh yang nyata terhadap berat basah akar. Berat basah akar pada pemberian mulsa jerami padi yang berbeda setelah 6 minggu tersaji pada Tabel 6 .

Hasil Uji DMRT menunjukkan bahwa perlakuan mulsa jerami memberikan perbedaan yang nyata terhadap berat basah akar. Berat basah akar mengalami peningkatan pada perlakuan 0 ton/ha sampai 4 ton/ha, namun kemudian berat basah akar menurun pada perlakuan 6 ton/ha dan menurun secara signifikan pada perlakuan 8 ton/ha. Perlakuan mulsa 4 ton/ha memberikan hasil lebih tinggi yaitu $18,34 \mathrm{~g}$ dibandingkan dengan perlakuan lainnya. Hal ini dikarenakan suhu dan kelembaban tanah pada perlakuan 4 ton/ ha merupakan suhu dan kelembaban tanah yang dikehendaki oleh tanaman kailan yaitu $76,40 \%$ dan $24^{\circ} \mathrm{C}$ sehingga memberikan hasil berat basah yang tinggi. Perlakuan 6 ton/ha dan 8 ton/ha suhu tanah menurun dan tidak sesuai dengan suhu yang dikehendaki tanaman kailan sehingga berat basah yang dihasilkan menjadi rendah. Menurut Emmyzar (2004) laju pertumbuhan tanaman akan

Tabel 6. Berat Basah akar pada Berbagai Perlakuan.

\begin{tabular}{cc}
\hline Mulsa Jerami Padi (ton/ha) & Berat Basah Akar (g) \\
\hline 0 & $249,6^{\mathrm{ab}}$ \\
2 & $251,8^{\mathrm{ab}}$ \\
4 & $341,8^{\mathrm{a}}$ \\
6 & $335,4^{\mathrm{a}}$ \\
8 & $206,0^{\mathrm{b}}$ \\
\hline Rata-rata & 276,92 \\
\hline
\end{tabular}

Superskrip yang berbeda pada kolom yang sama menunjukkan perbedaan nyata $(\mathrm{P}<0,05)$. 
sangat rendah apabila tanaman dikondisikan dibawah suhu minimum dan diatas suhu maksimum, sedangkan pada kisaran suhu optimum akan diperoleh laju pertumbuhan tanaman yang lebih tinggi.

\section{Berat Kering Tanaman dan Akar}

Hasil analisis ragam menunjukkan bahwa mulsa jerami padi tidak memberikan pengaruh yang nyata terhadap berat kering tanaman. Berat kering tanaman pada pemberian mulsa jerami padi yang berbeda setelah 6 minggu tersaji pada Tabel 7. ini didukung oleh Rymuza et al (2015) yang menyatakan bahwa suhu yang tidak stabil dapat menurunkan hasil karena mempengaruhi proses fisiologi dan biokimia pada tanaman seperti fotosintesis, respirasi dan turgiditas..

Hasil analisis ragam menunjukkan bahwa mulsa jerami padi memberikan pengaruh yang nyata terhadap berat kering tanaman. Berat kering tanaman pada pemberian mulsa jerami padi yang berbeda setelah 6 minggu tersaji pada Tabel 8 .

Hasil Uji DMRT menunjukkan bahwa perlakuan mulsa jerami padi memberikan perbedaan yang nyata tehadap berat kering akar.

Tabel 7. Rerata Berat kering Tanaman pada Berbagai Perlakuan.

\begin{tabular}{cc}
\hline Mulsa Jerami Padi (ton/ha) & Berat kering Tanaman $(\mathrm{g})$ \\
\hline 0 & 11,15 \\
2 & 10,52 \\
4 & 10,34 \\
6 & 10,93 \\
8 & 10,74 \\
\hline Rata-rata & 10,73 \\
\hline
\end{tabular}

Tabel 8. Berat kering Akar pada Berbagai Perlakuan

\begin{tabular}{cc}
\hline Mulsa Jerami Padi (ton/ha) & Berat kering Akar $(\mathrm{g})$ \\
\hline 0 & $46,43^{\mathrm{ab}}$ \\
2 & $49,01^{\mathrm{a}}$ \\
4 & $40,76^{\mathrm{ab}}$ \\
6 & $47,92^{\mathrm{ab}}$ \\
8 & $46,99^{\mathrm{b}}$ \\
\hline Rata-rata & 46,22 \\
\hline
\end{tabular}

Superskrip yang berbeda pada kolom yang sama menunjukkan perbedaan nyata $(\mathrm{P}<0,05)$.

Hasil Uji DMRT menunjukkan bahwa perlakuan mulsa jerami padi tidak berpengaruh nyata pada berat kering tanaman kailan. Hal tersebut dikarenakan perubahan suhu tanah setiap minggu pada setiap perlakuan tidak stabil sehingga menghambat pertumbuhan tinggi tanaman. Menurut Fardiansyah (2015) apabila suhu iklim mikro tidak stabil (naik turun) maka proses fisiologis terutama fotosintesis akan menurun dan produksi bahan kering menurun. Hal
Berat kering akar meningkat pada perlakuan mulsa jerami padi 0 ton/ha sampai 6 ton/ha dan mengalami penurunan yang signifikan pada perlakuan mulsa jerami padi 8 ton/ha. Berat kering akar tertinggi terjadi pada perlakuan 6 ton/ha. Hal ini dikarenakan suhu dan kelembaban pada perlakuan 6 ton/ha sesuai dengan yang dikehendaki tanaman kailan sehingga pertumbuhan menjadi baik dan produksi berat kering akar menjadi tinggi. Berat kering akar 
terendah terjadi pada perlakuan 8 ton/ha. Hal ini dikarenakan suhu tanah pada perlakuan 8 ton/ha tidak sesuai dengan suhu yang dikehendaki tanaman kailan sehingga pertumbuhan menjadi terhambat serta produksi menjadi rendah. Menurut Emmyzar (2004) laju pertumbuhan tanaman akan sangat rendah apabila tanaman dikondisikan dibawah suhu minimum dan diatas suhu maksimum, sedangkan pada kisaran suhu optimum akan diperoleh laju pertumbuhan tanaman yang lebih tinggi.

\section{Kandungan Klorofil Total Tanaman Kailan}

Hasil analisis ragam menunjukkan bahwa perlakuan mulsa jerami padi memberikan pengaruh yang nyata terhadap kandungan klorofil total tanaman kailan setelah 6 minggu. Kandungan klorofil total tanaman kailan pada pemberian mulsa jerami padi dengan takaran yang berbeda setelah 6 minggu tersaji pada Tabel 9 . tidak sesuai dengan suhu tanah optimum tanaman kailan serta kandungan air dalam tanah rendah maka akan menghambat laju fotosintesis, sehingga menghasikan klorofil total yang rendah. Menurut Hendriyani dan Setiari (2009) kurangnya ketersediaan air akan menghambat sintesis klorofil pada daun akibatnya laju fotosintesis menurun dan terjadinya peningkatan temperatur dan transpirasi yang menyebabkan disentegrasi klorofil.

\section{KESIMPULAN}

Perlakuan mulsa dengan takaran 6 ton/ha mampu meningkatkan hasil jumlah daun, berat kering akar dan kandungan klorofil total tetapi tidak meningkatkan hasil tinggi tanaman, kelembaban dan suhu tanah, berat basah tanaman dan akar, berat kering tanaman.

Tabel 9. Kandungan Klorofil Total Tanaman Kailan pada Berbagai Perlakuan.

\begin{tabular}{cc}
\hline Mulsa jerami padi (ton/ha) & Klorofil Total $(\mathrm{mg} / \mathrm{g})$ \\
\hline 0 & $0,77^{\mathrm{b}}$ \\
2 & $0,72^{\mathrm{bc}}$ \\
4 & $0,70^{\mathrm{bc}}$ \\
6 & $1,34^{\mathrm{a}}$ \\
8 & $0,56^{\mathrm{c}}$ \\
\hline Rata-rata & 0,81
\end{tabular}

Superskrip yang berbeda pada kolom yang sama menunjukkan perbedaan nyata $(\mathrm{P}<0,05)$.

Hasil Uji DMRT menunjukkan bahwa perlakuan mulsa jerami padi memberikan perbedaan yang nyata terhadap kandungan klorofil total pada tanaman kailan. Perlakuan 6 ton/ha memberikan hasil klorofil lebih tinggi dibandingkan dengan perlakuan lainnya. Hal ini dikarenakan kondisi iklim tanah seperti kelembaban dan suhu pada perlakuan 6 ton/ha sesuai dengan yang dikehendaki tanaman kailan dan kandungan air dalam tanah tercukupi, sehingga laju fotosintesis tidak terhambat dan menghasilkan klorofil total lebih tinggi dengan perlakuan lainnya. Perlakuan mulsa jerami padi 8 ton/ha menghasilkan klorofil total lebih rendah dengan perlakuan lainnya. Hal ini dikarenakan suhu tanah pada perlakuan 8 ton/ha menurun dan

\section{DAFTAR PUSTAKA}

Ariffin. 2005. Dasar-dasar Klimatologi Pertanian. Fakultas Pertanian, Univer-sitas Brawijaya. Tidak dipublikasikan.

Badan Pusat Statistik (BPS). 2014. Statistik Pertanian Hortikultura. Badan Pusat Statistik Provinsi Jawa Tengah.

Damaiyanti, D. R. R., N. Aini dan Koesriharti. 2013. Kajian penggunaan macam mulsa organik pada pertumbuhan dan hasil tanaman cabai besar (Capsicum annuum L.). J. Produksi Tanaman 1(2): 25 - 32. 
Emmyzar. 2004. Pengaruh ketersediaan air terhadap pertumbuhan dan produksi dua klon nilam. J. Littri 10(4): 159 - 165.

Fadriansyah, A. 2015. Pengaruh takaran mulsa jerami padi terhadap pertumbuhan dan hasil tanaman kedelai (Glycine max L). Statewide Agricultural Land Use Baseline 2015 1: 1-14.

Hendriyani, I. S dan N. Setiari. 2009. Kandungan klorofil dan pertumbuhan kacang panjang (Vigna sinensis) pada tingkat penyediaan air yang berbeda. J. Sains \& Mat. 17(3): 145 150.

Idris, M., A. Muin dan Burhanuddin. 2017. Pertumbuhan Aquilaria spp dengan pemberian pupuk kandang dan mulsa di tanah ultisol pada lahan terbuka. J. HUTAN LESTARI 5(3): 659 - 667.

Irfany, A., M. Nawawi dan T. Islami. 2016. Pemberian mulsa jerami padi dan pupuk hijau Crotalaria juncea L. pada pertumbuhan dan hasil tanaman jagung varietas kretek tambin. J. Prod Tan 4(6): $454-461$

Kartasapoetra, G. A. 2004. Klimatologi : Pengaruh Iklim terhadap Tanah dan Tanaman. Bumi Aksara, Jakarta.

Mayun, I. A. 2007. Efek mulsa jerami padi dan pupuk kandang sapi terhadap pertumbuhan dan hasil bawang merah di daerah pesisir. $J$. Agritrop 26(1): 33 - 40.
Rymuza, R., Radzka and Lenartowicz, T., 2015. Effect of weather conditions on early potato yields in east-central Poland. Communications in Biometry and Crop Science 10(2): 65-72.

Samiati., A. Bahrun2 dan L. O. Safuan. 2012. Pengaruh takaran mulsa terhadap pertumbuhan dan produksi sawi (Brassica juncea L.) J. Agronomi 1(2): 121 - 125.

Suharyanto dan E. Sulistiawati. 2012. Teknologi Budidaya Kailan dalam Pot. Balai Pengkaji Teknologi Pertanian (BPTP). Jambi.

Suminarti, N. E. 2012. Dasar Klimatologi. Jurusan Budidaya Pertanian, Fakultas pertanian, Universitas Brawijaya.

Trisnaningsih, U., E. N. Handayani dan D. Budirokhman. 2015. Pengaruh bobot mulsa jerami padi terhadap pertumbuhan dan hasil tanaman kacang hijau (Vigna radiata L.) kultivar kutilang. J. AGROSWAGATI 1(3): 274 - 277.

Widyasari, L., T. Sumarni dan Ariffin. 2011. Pengaruh sistem olah tanah dan mulsa jerami padi pada pertumbuhan dan hasil kedelai. Agrivita 9(8): 93 - 101.

Yulinda, Z., W. Pembengo dan F. Zakaria. 2013. Pertumbuhan dan hasil tanaman caisim (Brassica juncea L.) berdsarkan variasi mulsa dan jarak tanam. J. Agrotekbis 3(5): 2 -13 . 